\title{
SIMULASI KOMPUTASIONAL BEDA HINGGA 2D ANALISA TRANSPORT MASSA EFEK PARAMETER DESAIN DAN OPERASI TERHADAP KINERJA PEM FUEL CELL
}

\author{
Hariyotejo Pujowidodo \\ Balai Teknologi Termodinamika Motor Propulsi (BT2MP) BPP Teknologi \\ Kawasan Puspiptek Serpong Tangerang Selatan Banten 15314 \\ Email: hariyotejo.pujowidodo@bppt.go.id
}

\begin{abstract}
ABSTRAK
Studi ini merupakan hasil kegiatan dalam analisa pengembangan sebuah alternative sumber energy terbarukan teknologi hydrogen yang dinamakan sel tunam membrane pertukaran proton (PEM Fuel Cell), melalui analisa pemodelan transport massa pada domain komputasi 2 dimensi dari kanal gas, pelat bipolar, lapisan difusi dan membrane pada kedua electrode. Beberapa hasil akan disampaikan melalui parameter post processing; kontur, vektor yang ada di dalam tools, berupa distribusi spesies reaktan (hydrogen, oksigen dan humidity $\mathrm{H}_{2} \mathrm{O}$ ) ataupun produk $\left(\mathrm{H}_{2} \mathrm{O}\right)$ di masing-masing electrode (anode dan katode). Selanjutnya data hasil tersebut dikaji berdasarkan teori analisa tentang kinetika reaksi yang terjadi, guna diperoleh factor utama yang mempengaruhi kinerja densitas arus yang dihasilkan. Dari hasil simulasi pada parameter optimum operasi dan desain yaitu sebesar tekanan statis 15 psi.g, temperature saturasi air $70^{\circ} \mathrm{C}$, tegangan listrik 0,6 volt, porositas lapisan difusi 0,4 , porositas lapisan katalis 0,6 dan kedalaman rib $1 \mathrm{~mm}$, diperoleh nilai optimasi densitas arus katalis anode sebesar $10750 \mathrm{~A} / \mathrm{m}^{2}$.
\end{abstract}

Kata kunci: densitas arus, parameter desain dan operasi, domain, PEMFC, spesies.

\begin{abstract}
This study presents the activity of 2 Dimensional Mass Transport PEM Fuel Cell Modelling, by means of computation domain in gas channel, bipolar plate, difusion layer and electrolyte membrane of the both electrodes. The parameter results would be given in post processing, such as contour, vector tools, like reactant species distribution (hydrogen, oxygen and humidity) as well vapor product in each electrodes (anode and cathode). Based on analysis of reaction kinetics, would be investigated the prominent factor affecting current density performance. From the simulation, it has been obtained that the optimum design and operation are in the prossure condition of $15 \mathrm{psig}$, water saturation temperature of $70^{\circ} \mathrm{C}$, potential of 0.6 volts, difusion layer porosity of 0.4 , catalyst layer porosity of 0.6 and the rib of $1 \mathrm{~mm}$. This optimum condition could give the current density $1075 \mathrm{~A} / \mathrm{m}^{2}$.
\end{abstract}

Keywords: current density, design and operation parameters, domain, PEMFC, species.

\section{PENDAHULUAN}

Berkurangnya jumlah cadangan energi fosil dan dampak emisi rumah kaca gas $\mathrm{CO}_{2}$ pada perubahan iklim global telah mendorong dikembangkannya teknologi energi alternatif terbarukan ramah lingkungan, di antaranya yang dinamakan Sel Tunam Membrane Pertukaran Proton (Proton Exchange Membrane Fuel Cell, PEM Fuel Cell). PEM Fuel Cell merupakan perangkat konversi energi listrik melalui reaksi elektrokimia bahan bakar hidrogen $\left(\mathrm{H}_{2}\right)$ dan oksigen $\left(\mathrm{O}_{2}\right)$, yang terjadi pada lapisan membrane elektrolit konduktif pertukaran proton. Lapisan membrane elektrolit adalah media polimer porus sangat tipis, perantara reaktan yang mengalir pada elektroda, yang terdiri dari lapisan difusi gas dari serat karbon dan elektrolit dengan struktur katalis konduktif ion untuk menghasilkan perpindahan massa proses konveksi gas dan muatan listrik.

Reaksi elektrokimia berupa perpindahan massa dan muatan di lapisan katalis, bergantung kepada faktor laju kinetika reaksi yaitu kecepatan reaktan yang melalui struktur membrane elektrolit terhumidifikasi, material konduktif membrane dan elektrode, medan aliran pada kanal laluan di elektrode. Transport massa dan muatan menentukan besarnya densitas arus listrik yang dihasilkan, merupakan perpindahan momentum dan difusi massa dalam proses reduksi oksidasi reaktan $\mathrm{H}_{2}$ dan $\mathrm{O}_{2}$. Hasil proses tersebut menghasilkan produk air, yang selanjutnya juga akan mempengaruhi kemampuan hantaran 
molekul air di membrane untuk membawa ion proton (electro osmotic drag) selain yang terlarut di dalam gas reaktan (humiditas). Proses reaksi tersebut sebagaimana ditunjukkan dalam gambar 1.

Beberapa studi melalui analisis komputasional dan numerikal banyak dilakukan guna mengkaji parameter-parameter yang mempengaruhi kinerja dari PEM Fuel Cell dan upaya dalam mengembangkan hasil yang lebih optimal. Di antara analisa pemodelan adalah pemodelan komputasi tentang pengaruh geometri, parameter operasi seperti tekanan, temperatur, porositas difusi, tegangan dan humiditas [1-7]. Pola aliran kanal melalui aliran sejajar(paralel) dan aliran berkelok (serpentine) memberikan perbedaan densitas arus, di mana pola serpentine akan menghasilkan densitas arus yang lebih baik pada beberarapa parameter operasi tekanan, temperatur, dan humiditas [1]. Tekanan merupakan parameter utama yang sangat menentukan kinerja densitas arus terhadap proses difusi konveksi reaktan [2]. Porositas difusi dan potensial sangat mempengaruhi laju kinetika reaksi untuk menghasilkan densitas arus [4-6]. Humiditas dalam proses elektrokimia memiliki pengaruh penting dalam menghasilkan kinerja densitas arus terutama pada sisi anode [7]. Kinerja densitas arus yang dihasilkan oleh PEM Fuel Cell juga telah dikaji melalui analisa pemodelan beda hingga 2 dimensi (2D) dan 3 dimensi (3D), dengan menerapkan persamaan konservasi massa (kontinuitas), momentum Navier-Stokes, hukum Darcy medium porus, persamaan difusi konveksi Maxwell-Stefan dan kesetimbangan muatan arus persamaan Butler Volmer [8-11].

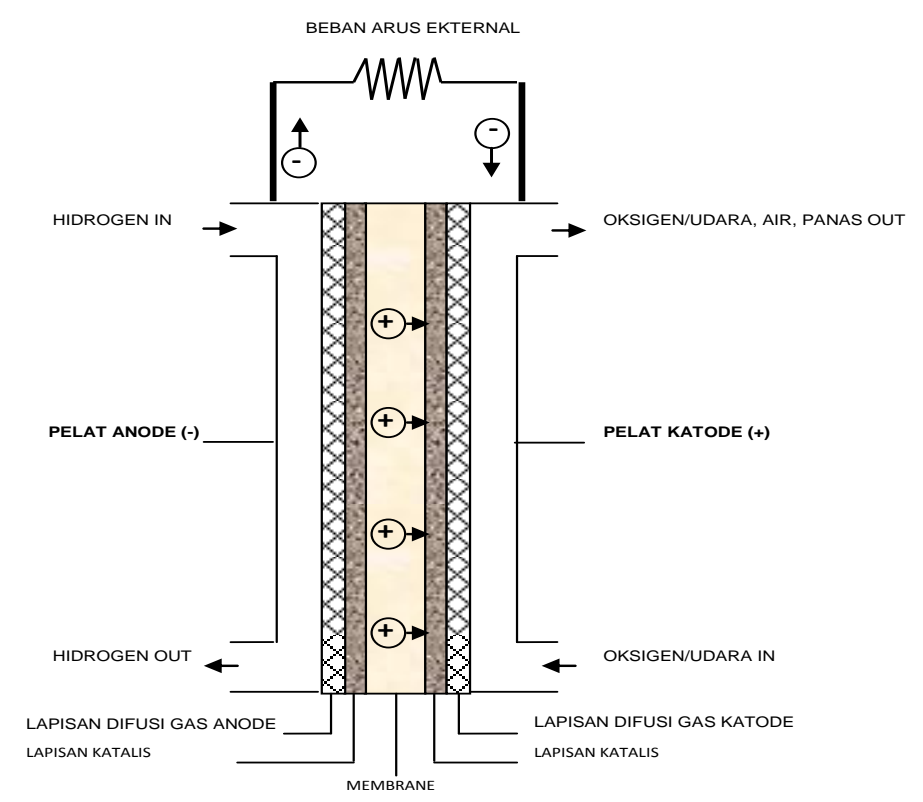

Gambar 1. Mekanisme Transport Massa dan Muatan pada PEM Fuel Cell

Dalam studi ini akan dilakukan analisa transport massa efek parameter desain dan operasi berupa tekanan, temperatur, porositas, kedalaman bidang pelat kolektor arus pada lapisan difusi gas (rib depth) serta potensial listrik, melalui pemodelan perangkat komputasional 2 D. Langkah analisa dilakukan mulai dari tahap pendefinisian kondisi batas model, persamaan konservasi massa, momentum, spesies dan muatan listrik, tahap pembentukan elemen hingga, perhitungan kondisi awal hingga konvergensi hasil, dan diakhiri dengan tahap post processing berupa penampilan hasil distribusi kinerja densitas arus. Dari hasil pemodelan diperoleh bahwa tekanan, temperatur, porositas, kedalaman dan potensial memiliki pengaruh utama dalam memberikan difusi konveksi perpindahan massa dalam reaksi elektrokimia untuk menghasilkan kinerja densitas arus.

\section{METODOLOGI PENELITIAN}

Untuk memudahkan dalam melakukan pemodelan ini, maka disusun sistematika rangkaian kegiatan yang terbagi atas tahap penetapan hipotesa/batasan, tahap kedua yaitu pemodelan (modelisasi) dan tahap ketiga berupa tahap pelaksanaan (implementasi). Selengkapnya masing-masing tahapan tersebut akan diuraikan berikut ini. 


\subsection{Hipotesa/Batasan (Constraints)}

Dalam melakukan pemodelan komputasi 2 D dengan metode/teknik beda hingga, terlebih dahulu ditetapkan beberapa batasan pemodelan dan beberapa idealisasi yang diambil untuk menyederhanakan dalam simulasi. Sebagai batasan dalam pemodelan adalah sebuah area transversal dari system sel tunam yang terdiri atas penampang area GDL, membrane (termasuk katalis) dari anode dan katode, sebagaimana ditunjukkan dalam gambar 2 di bawah ini.
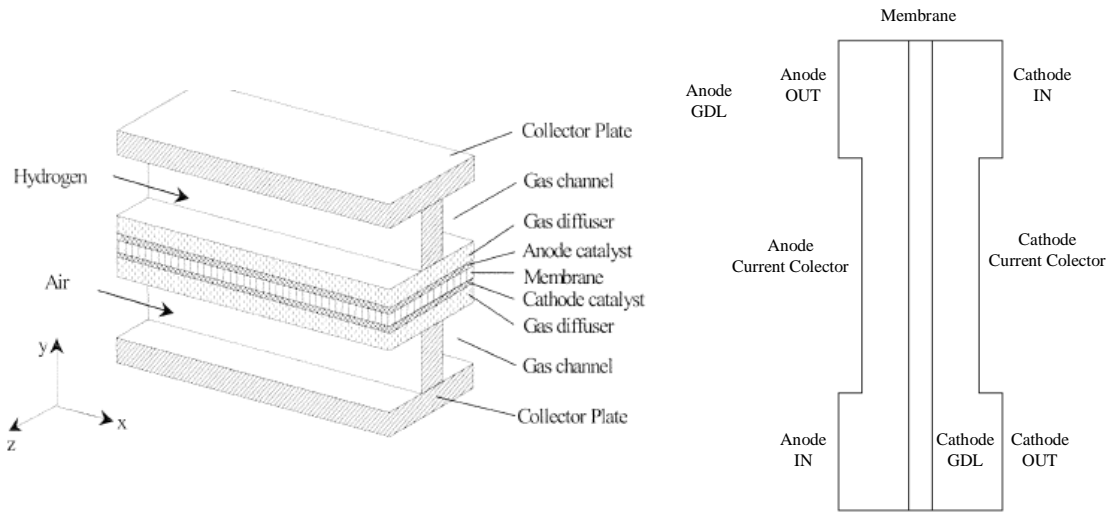

\section{Gambar 2. Penampang Area Batasan Model [6]}

Batasan/hipotesa lainnya adalah sebagai berikut :

a) Aliran merupakan gas ideal isothermal pada kondisi steady state.

b) Material homogen isotropic (propertis dan struktur molekuler).

c) Membrane terhumidifikasi dalam kondisi saturasi/jenuh air.

d) Pada lapisan katalis terdapat kesetimbangan fluks konvektif dan difusi massa

e) Tegangan normal pada pelat bipolar adalah seragam pada area bawah pelat ( $r i b$ )

\subsection{Modelisasi (Modelling)}

Tahap modelisasi diawali dari pendefinisian batas/lingkup system model (domain) yaitu batasan area pemodelan secara 2 dimensI, terbagi atas area lapisan difusi gas anode $\Omega$ a dan katode $\Omega$ c, area membrane $\Omega \mathrm{m}$ yang dibatasi langsung oleh sisi lapisan katalis anode $\delta \Omega \mathrm{a}$ dan katode $\delta \Omega \mathrm{c}$, dari area 2 kanal berdampingan yang dibatasi oleh pelat bipolar (current collector) $\delta \Omega \mathrm{a}, \mathrm{cc}, \delta \Omega \mathrm{c}, \mathrm{cc}$, serta saluran masuk reaktan anoda $\delta \Omega$ a,inlet dan katoda $\delta \Omega$ c,inlet. Secara rinci domain komputasi digambarkan seperti dijelaskan pada gambar 2 di atas dan gambar 3 di bawah ini

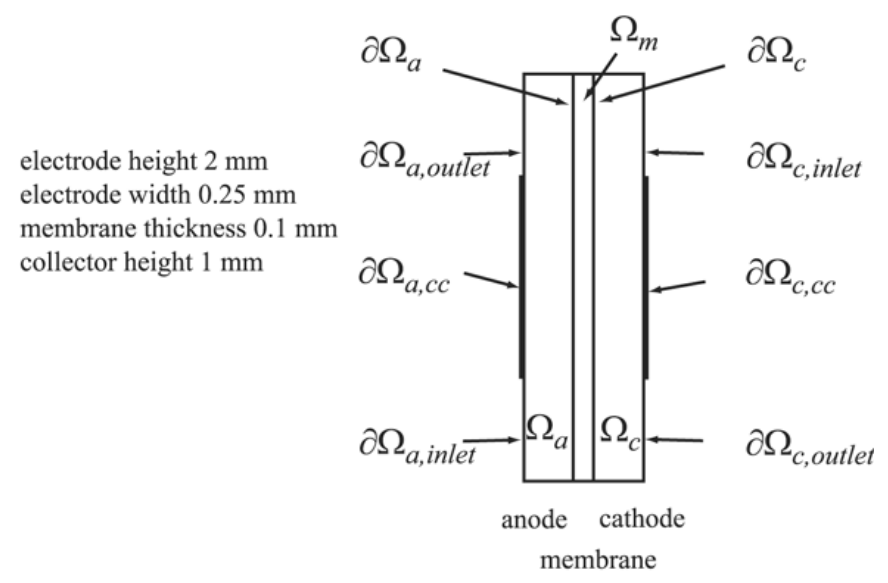

Gambar 3. Model geometri sub domain dan sisi batas [6] 
Batasan variable simulasi (boundary conditions) yang merupakan parameter dari suatu proses reaksi yang ditentukan dalam kajian transport massa ini yaitu parameter tekanan (5 psi.g; 10 psi.g; 15 psi.g), potensial listrik $(0,6$ volt; 0,7 volt; 0,8 volt $)$, temperature $\left(70{ }^{\circ} \mathrm{C} ; 80{ }^{\circ} \mathrm{C} ; 90{ }^{\circ} \mathrm{C}\right)$, fraksi massa spesies $(10$ $\left.\% \mathrm{H}_{2} ; 80 \% \mathrm{O}_{2}\right)$, porositas difusi $(0,2 ; 0,4 ; 0,6)$. Untuk properties ,material seperti konduktivitas, porositas, viskositas, permeabilitas digunakan dari data yang tersedia di dalam perangkat.

Beberapa persamaan atur (governing equations) yang digunakan untuk menyelesaikan komputasi numerik sesuai kondisi batas terdiri dari persamaan (1) hingga (11) berikut ini [3,6,8,9,10].

Kontinuitas adalah persamaan konservasi untuk massa aliran yang melalui sebuah sistem volume atur dalam hal ini yang melewati domain kanal gas, lapisan difusi dan lapisan katalis.

$\frac{\partial(\rho \varepsilon u)}{\partial x}+\frac{\partial(\rho \varepsilon v)}{\partial x}+\frac{\partial(\rho \varepsilon w)}{\partial x}=S_{m}$ atau $\nabla \varepsilon \rho \mathbf{u}=S_{m}$

di mana $\rho, \varepsilon$ adalah densitas fluida, porositas difusi dan $u, v, w$ merupakan komponen kecepatan arah $\mathrm{x}$, y,z. $S_{m}$ menunjukkan suku sumber dari massa yang timbul akibat reaksi elektrokimia (konsumsi $\mathrm{H}_{2}$ serta $\mathrm{O}_{2}$ dan produksi air di katoda). $\nabla$ adalah operator gradien fungsi derivatif 3 komponen.

Momentum yaitu persamaan kesetimbangan adanya kecepatan yang dibawa oleh massa aliran fluida melalui suatu sistem volume atur domain kanal gas, lapisan difusi dan lapisan katalis.

$$
\begin{aligned}
& u \frac{\partial(\rho \varepsilon u)}{\partial x}+v \frac{\partial(\rho \varepsilon v)}{\partial x}+w \frac{\partial(\rho \varepsilon w)}{\partial x}=-\varepsilon \frac{\partial p}{\partial x}+\frac{\partial}{\partial x}\left(\mu \varepsilon \frac{\partial u}{\partial x}\right)+\frac{\partial}{\partial y}\left(\mu \varepsilon \frac{\partial v}{\partial y}\right)+\frac{\partial}{\partial z}\left(\mu \varepsilon \frac{\partial w}{\partial z}\right)+S_{p x} \\
& u \frac{\partial(\rho \varepsilon u)}{\partial x}+v \frac{\partial(\rho \varepsilon v)}{\partial x}+W \frac{\partial(\rho \varepsilon w)}{\partial x}=-\varepsilon \frac{\partial p}{\partial y}+\frac{\partial}{\partial x}\left(\mu \varepsilon \frac{\partial u}{\partial x}\right)+\frac{\partial}{\partial y}\left(\mu \varepsilon \frac{\partial v}{\partial y}\right)+\frac{\partial}{\partial z}\left(\mu \varepsilon \frac{\partial w}{\partial z}\right)+S_{p y} \\
& u \frac{\partial(\rho \varepsilon u)}{\partial x}+v \frac{\partial(\rho \varepsilon v)}{\partial x}+W \frac{\partial(\rho \varepsilon w)}{\partial x}=-\varepsilon \frac{\partial p}{\partial z}+\frac{\partial}{\partial x}\left(\mu \varepsilon \frac{\partial u}{\partial x}\right)+\frac{\partial}{\partial y}\left(\mu \varepsilon \frac{\partial v}{\partial y}\right)+\frac{\partial}{\partial z}\left(\mu \varepsilon \frac{\partial w}{\partial z}\right)+S_{p z}
\end{aligned}
$$

atau jika dituliskan dengan fungsi operator vector, untuk 3 komponen x,y,z, menjadi

$\boldsymbol{u} \nabla(\rho \varepsilon \mathbf{u})=-\nabla \boldsymbol{P}+\nabla(\rho \mu \mathbf{u})+S_{p}$

untuk $\mu$ adalah viskositas dinamik, $P$ tekanan fluida dan $S_{p x} S_{p y}, S_{p z}$ adalah sumber yang diakibatkan adanya perubahan tekanan yang terjadi pada medium porus. (Hukum Darcy).

$S_{p v}=\frac{\mu u}{\beta_{x}} ; S_{p y}=\frac{\mu v}{\beta_{y}} ; \quad S_{p z}=\frac{\mu w}{\beta_{x}}$

di mana $\beta_{x}, \beta_{x}, \beta_{z}$ adalah permeabilitas hidrolis elektroda, yang besarnya sama ke 3 arah (isotropic).

Spesies dan Energi yaitu persamaan konservasi untuk molekul kimia reaktan i $\left(\mathrm{H}_{2}, \mathrm{O}_{2}, \mathrm{~N}_{2}, \mathrm{H}_{2} \mathrm{O}\right)$ yang bereaksi menghasilkan produk, yang terjadi pada area lapisan difusi, membrane dan katalis. Persamaan difusi konveksi menggunakan persamaan Maxwell-Stefan berikut.

$\nabla\left[-\rho \omega_{\mathrm{i}} \sum_{\mathrm{j}=\mathrm{i}}^{\mathrm{n}} \mathrm{D}_{\mathrm{ij}}\left(\frac{M}{M_{\mathrm{i}}}\left(\nabla \omega_{\mathrm{j}} \frac{\nabla M}{M}\right)+\left(\mathrm{x}_{\mathrm{j}}-\omega_{\mathrm{j}}\right) \frac{\nabla P}{P}+\omega_{\mathrm{i}} \rho \mathbf{u}+\mathrm{D}_{\mathrm{i}}^{\mathrm{T}} \frac{\nabla \mathrm{T}}{\mathrm{T}}\right]=\mathrm{R}_{\mathrm{i}}\right.$

di mana $\mathrm{D}_{\mathrm{ij}}=$ koefisien difusi $\left(\mathrm{m}^{2} / \mathrm{s}\right), \mathrm{p}=$ tekanan $(\mathrm{Pa}), \mathrm{T}=$ temperature $(\mathrm{K}), \mathbf{u}=$ vector kecepatan $(\mathrm{m} / \mathrm{s}), \mathrm{x}$ $=$ mol, $\omega=$ fraksi massa, $\rho=$ densitas $\left(\mathrm{kg} / \mathrm{m}^{3}\right)$

Densitas merupakan fungsi fraksi mol dan massa molal (M, $\mathrm{kg} / \mathrm{mol})$

$\rho=\Sigma_{\mathrm{i}} x_{\mathrm{i}} M_{\mathrm{i}} \frac{p}{R T}$

Pada lapisan katalis, laju reaksi $\mathrm{R}_{\mathrm{i}}$ untuk laju konsumsi dan produksi masing-masing spesies diberikan sebagai berikut.

$R_{H_{2}}=-\frac{\tilde{j}}{2 F} M_{H_{2}} ; R_{O_{2}}=-\frac{\tilde{j} c}{4 F} M_{H_{2}} ; R_{H_{2} O}=-\frac{\tilde{j} c}{4 F} M_{H_{2} O}$ 
Di mana $\mathrm{F}$ adalah konstanta Faraday $(\mathrm{C} / \mathrm{mol})$ dan $\mathrm{j}_{\mathrm{a}}, \mathrm{j}_{\mathrm{c}}$ densitas arus transfer lokal di lapisan katalis anoda dan katoda yang ditentukan menurut Persamaan Buttler-Volmer.

Muatan listrik menggunakan persamaan konservasi muatan arus ionic dan elektronis yang terjadi akibat adanya perpindahan ion proton (melalui membrane) dan electron (yang melewati beban luar, melalui kolektor arus). Kontinuitas arus dari persamaan Ohm dituliskan sebagai berikut.

$\nabla \cdot\left(-\sigma_{g} \nabla \cdot \emptyset_{g}\right)=S_{s}$ (untuk electron) ; $\nabla \cdot\left(-\sigma_{m} \nabla \cdot \emptyset_{m}\right)=S_{m}$ (untuk proton)

Di sini $\emptyset_{s}=$ potensial fase (volt),$\sigma=$ konduktivitas listrik efektif (S/m) dan subskrip s dan $\mathrm{m}$ adalah fase solid kolektor dan membrane. $\mathrm{S}=$ suku sumber hasil reaksi elektrokimia yang terjadi di lapisan katalis dan ditunjukan oleh persamaan berikut.

$\mathrm{S}_{\mathrm{m}}=\mathrm{j}_{\mathrm{a}} ; \mathrm{S}_{\mathrm{s}}=-\mathrm{j}_{\mathrm{a}}$ (untuk katalis anoda) dan $\mathrm{S}_{\mathrm{m}}=\mathrm{j}_{\mathrm{c}} ; \mathrm{S}_{\mathrm{s}}=-\mathrm{j}_{\mathrm{c}}$ (untuk katalis katoda)

\subsection{Implementasi (Simulation)}

Pemodelan menggunakan aplikasi simulasi COMSOL dengan teknik penyelesaian (solver) elemen hingga untuk komputasi numerik persamaan-persamaan atur. Solver non linear stationary digunakan karena suku-suku sumber merupakan persamaan konservasi arus yang membuat permasalahan non linear. Akibatnya konvergensi iteratif perhitungan sangat dipengaruhi oleh nilai awal perhitungan. Terdapat modul kalkulasi untuk penyelesaian yaitu modul DC Media Konduktif untuk penyelesaian pertama dari input nilai awal, kedua yaitu modul Navier- Stokes Inkompresibel dan Hukum Darcy yang akan memberikan hasil perhitungan simultan kondisi awal. Sesudah kedua modul tersebut mencapai konvergensi dalam perhitungan iteratifnya, semua modul termasuk difusi konveksi Maxwell-Stefan akan diselesaikan secara simultan untuk nilai konvergensi akhir. Beberapa pendefinisan domain geometri dan kondisi batas disampaikan dalam gambar 4 berikut.

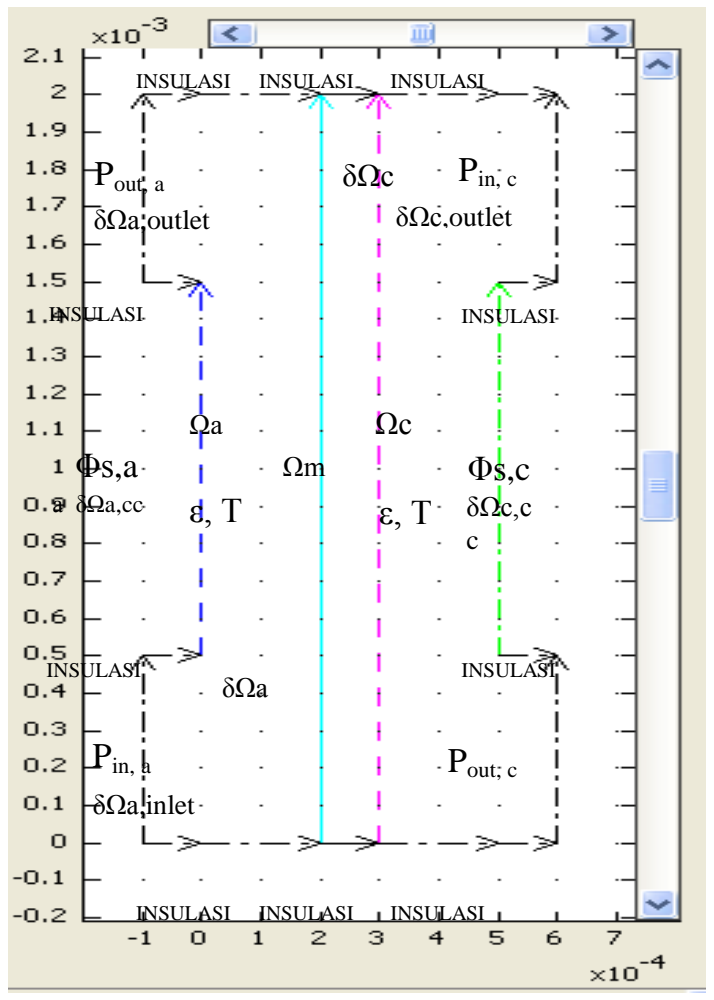

Gambar 4. Modelisasi fisik dan kondisi batas

Pada gambar 4, geometri domain komputasi yang didefinisikan berupa area domain pada lapisan difusi gas anoda $(\Omega \mathrm{a})$, membrane $(\Omega \mathrm{m})$ dan lapisan difusi gas katoda $(\Omega \mathrm{c})$. Untuk kondisi batas digunakan terminology sub domain pada sisi saluran masuk dan keluar anoda ( $\delta \Omega \mathrm{a}$, inlet dan $\delta \Omega a$, outlet), sisi kolektor arus anoda $(\delta \Omega \mathrm{a}, \mathrm{cc})$, sisi lapisan katalis anoda $(\delta \Omega \mathrm{a})$, sisi saluran masuk dan keluar katoda 
( $\delta \Omega \mathrm{c}$, inlet dan $\delta \Omega \mathrm{c}$, outlet), sisi kolektor arus katoda $(\delta \Omega \mathrm{c}, \mathrm{cc})$ dan sisi lapisan katalis anoda $(\delta \Omega \mathrm{c})$. Nilai kondisi batas pada masing-masing sisi tersebut meliputi besaran potensial listrik, temperature, tekanan operasi, dan porositas, diberikan dalam tabel 1 berikut ini.

Tabel 1. Parameter Simulasi dan Konstanta

\begin{tabular}{|c|c|c|c|c|}
\hline No & Parameter Simulasi & $\begin{array}{l}\text { Nilai dan } \\
\text { Satuan }\end{array}$ & $\begin{array}{c}\text { Notasi } \\
\text { Tools }\end{array}$ & Simbol/Lokasi \\
\hline 1 & $\begin{array}{l}\text { Electrical Potential } \\
\text { (anode) }\end{array}$ & 0 (volt) & fisa0 & $\delta \Omega \mathrm{a}, \mathrm{cc}$ \\
\hline 2 & $\begin{array}{l}\text { Electrical Potential } \\
\text { (katode) }\end{array}$ & $\begin{array}{l}0,6 ; 0,7 ; 0,8 \\
\quad \text { (volt) }\end{array}$ & Vcell & $\delta \Omega \mathrm{c}, \mathrm{cc}$ \\
\hline 3 & Temperatur & $70,80,90\left({ }^{\circ} \mathrm{C}\right)$ & $\mathrm{T}$ & $\delta \Omega \mathrm{a}$,inlet \\
\hline 4 & Tekanan masuk (anode) & $5,10,15$ (psig) & Pa_in & $\delta \Omega a$,inlet \\
\hline 5 & Tekanan masuk (katode) & $5,10,15$ (psig) & Pc_in & $\delta \Omega \mathrm{c}$,inlet \\
\hline 6 & Tekanan keluar & $101325 \mathrm{~Pa}$ & Pref & $\delta \Omega \mathrm{a} \& \mathrm{c}$, outlet \\
\hline 7 & Porositas lapisan difusi & 0,$2 ; 0,4 ; 0,6$ & emic & $\varepsilon$ \\
\hline 8 & Fraksi massa hidrogen & 0,1 & $\omega \mathrm{H}_{2}$ in & $\delta \Omega a$,inlet \\
\hline 9 & Fraksi massa oksigen & $21 \% * 0,8$ & $\omega \mathrm{O}_{2}$ in & $\delta \Omega \mathrm{c}$, inlet \\
\hline 10 & Fraksi massa $\mathrm{H}_{2} \mathrm{O}$ (uap) & 0,2 & $\omega \mathrm{H}_{2} \mathrm{O}$ & $\delta \Omega \mathrm{a} \& \mathrm{c}$,inlet \\
\hline
\end{tabular}

Untuk pembuatan grid/mesh, seperti dalam gambar 5 dan 6, digunakan setting default yang ada, diinisialisasi dengan menggunakan kualitas mesh sparse dan refine mesh untuk eksekusi perhitungan komputasi. Komputasi dilakukan menggunakan toolbar simulasi sesuai default yang ada di dalam solver manager dan mengubah solver Direct (UMFPACK) yang ada di dalam solver parameter.

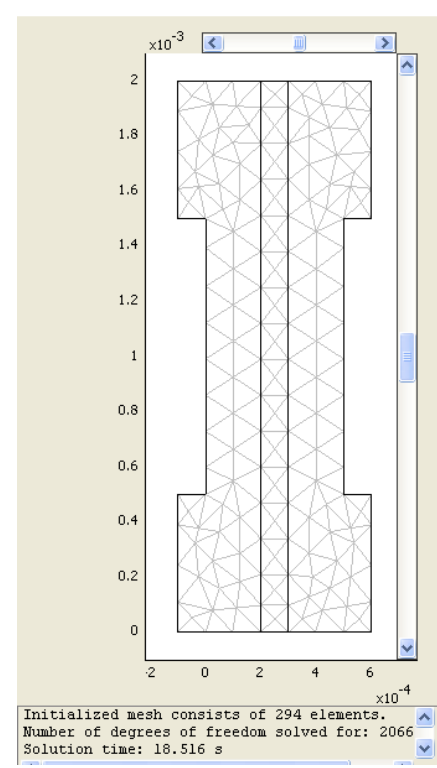

(a) Inisial Mesh (coarse)

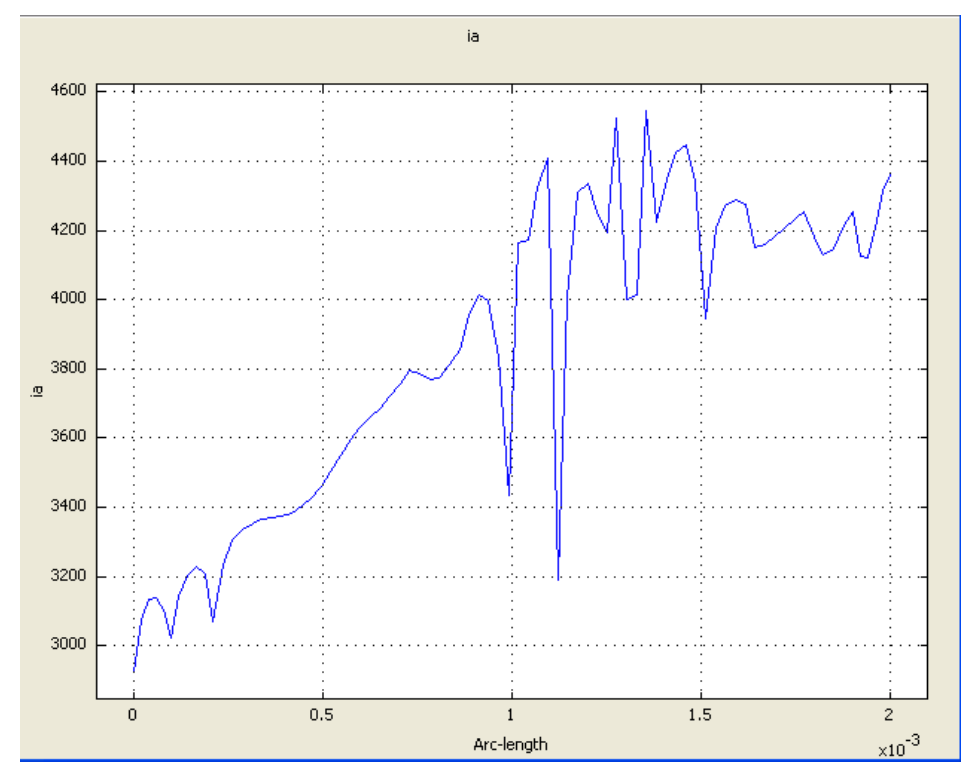

(b) Inisial hasil $i_{a}$ pada lapisan katalis

Gambar 5. tahap awal meshing dan hasil densitas arus pada katalis anode 


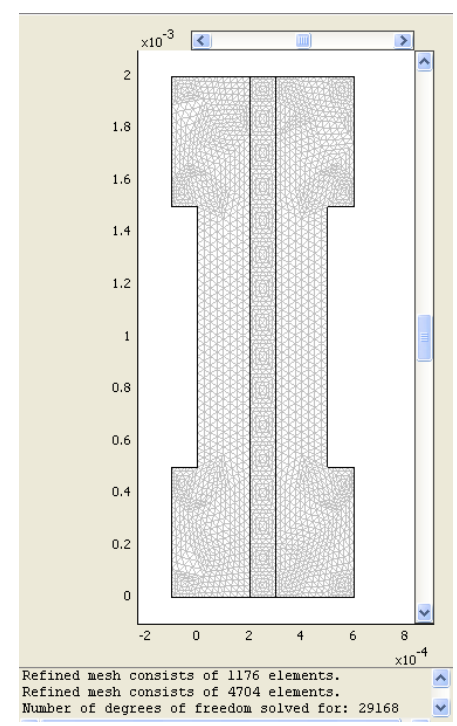

(a) Inisial Mesh (Refine)

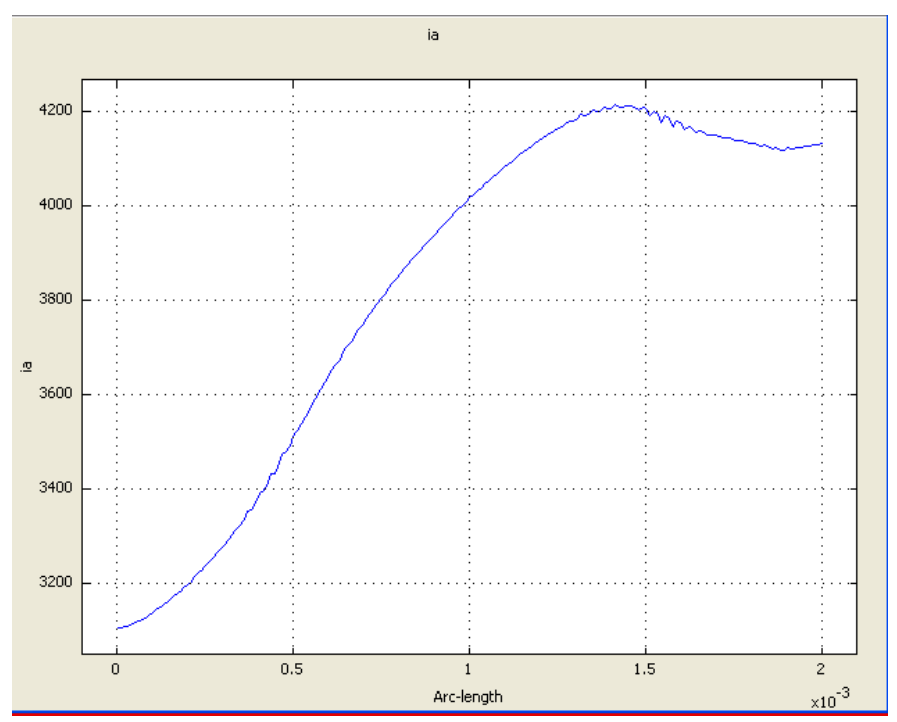

(b) Inisial hasil $i_{a}$ pada lapisan katalis

Gambar 6. Refine meshing dan hasil densitas arus pada katalis anode sebagai nilai kondisi awal

\section{HASIL PENELITIAN DAN PEMBAHASAN}

Pada gambar 6 hasil inisialisasi kondisi batas awal menunjukkan bahwa distribusi densitas arus local pada lapisan katalis anoda tidak sama, ia mencapai nilai maksimum sebesar $4200 \mathrm{~A} / \mathrm{m}^{2}$ (sebagai nilai kondisi awal, initial condition) pada jarak 1,5 $\mathrm{mm}$ tepatnya pada sisi atas kolektor arus anoda. Pada lokasi tersebut laju kinetika reaksi optimum di mana fluks massa $\mathrm{H}_{2}$ dan $\mathrm{O}_{2}$ dalam laju reaksi reduksi $\mathrm{O}_{2}$ menentukan distribusi densitas arus yang terjadi.

Sesuai dengan batasan analisa yang diberikan bahwa akan dikaji hasil model komputasi dari sub domain electrode dan membrane pengaruh parameter desain dan operasi yaitu temperature, tekanan,, tegangan, porositas dan rib yang masing-masing dituliskan kembali di dalam tabel 2 berikut.

Tabel 2. Parameter Desain dan Operasi

\begin{tabular}{cccc}
\hline No & Parameter Simulasi & Besaran Nilai & Satuan \\
\hline 1 & Tekanan inlet reaktan & $5,10,15$ & Psi.g \\
2 & Temperatur operasi & $343,353,363$ & ${ }^{\mathrm{o}} \mathrm{K}$ \\
3 & Tegangan Operasi & 0,$6 ; 0,7 ; 0,8$ & $\mathrm{~V}$ \\
4 & Porositas lapisan difusi & 0,$2 ; 0,4 ; 0,6$ & - \\
5 & Kedalaman pelat elektrode & $1 ; 1,25 ; 1,5$ & $\mathrm{~mm}$ \\
\hline
\end{tabular}

Sementara itu diberikan pula beberapa parameter analisa hasil pemodelan yang meliputi distribusi parameter dinamik aliran seperti tekanan statis, kecepatan; distribusi massa spesies maupun distribusi densitas arus sebagai parameter indikator utama dalam analisa simulasi sel tunam ini berdasarkan parameter/variabel simulasi yang terdapat di dalam tabel 2. Selengkapnya masing-masing hasil simulasi tersebut disajikan dalam uraian berikut ini.

a. Simulasi tekanan operasi 10,15 (psi.g) pada sisi inlet anode dan katode pada gambar 7 dan 8 menunjukkan bahwa Nilai tekanan operasi berbanding lurus terhadap densitas arus 


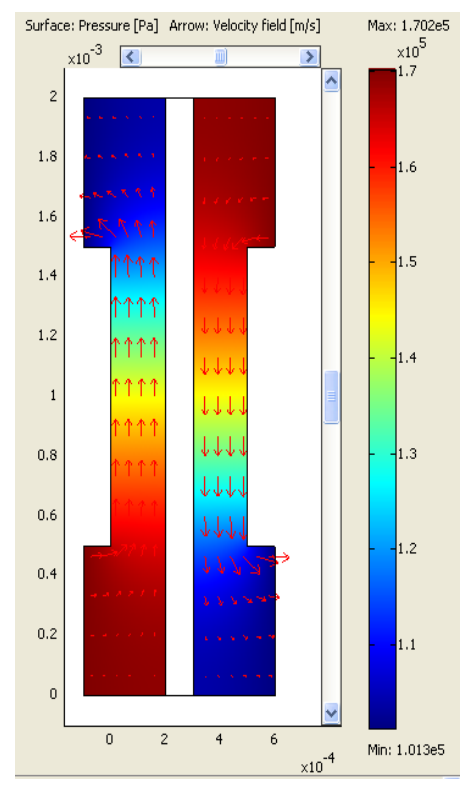

(a) Distribusi Tekanan

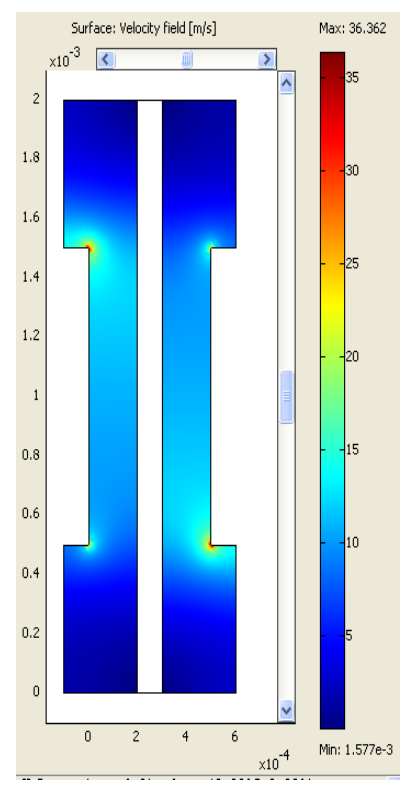

(b) Distribusi kecepatan

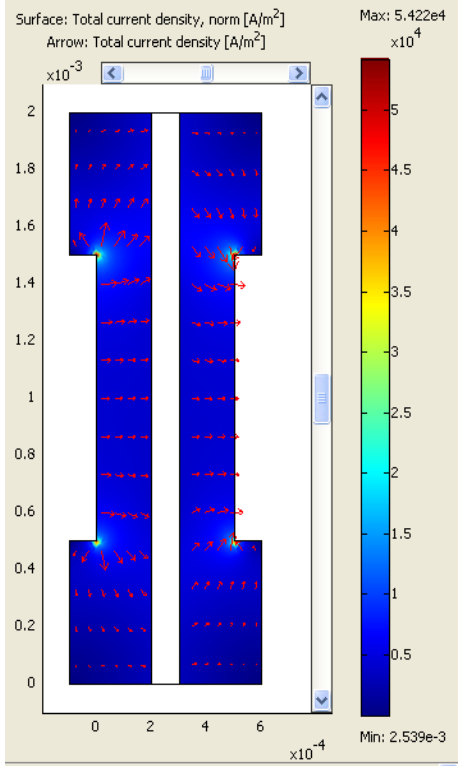

(c) Distribusi densitas arus

Gambar 7. Hasil Simulasi Tekanan Inlet Pa_in $=$ Pc_in $=10$ psi.g

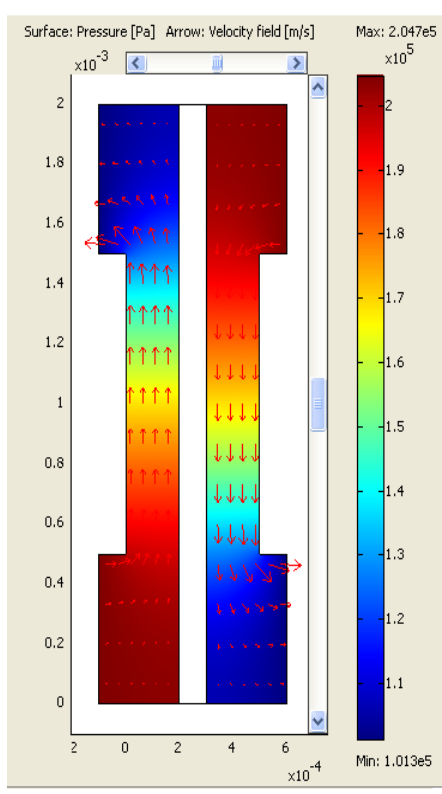

(a) Distribusi Tekanan

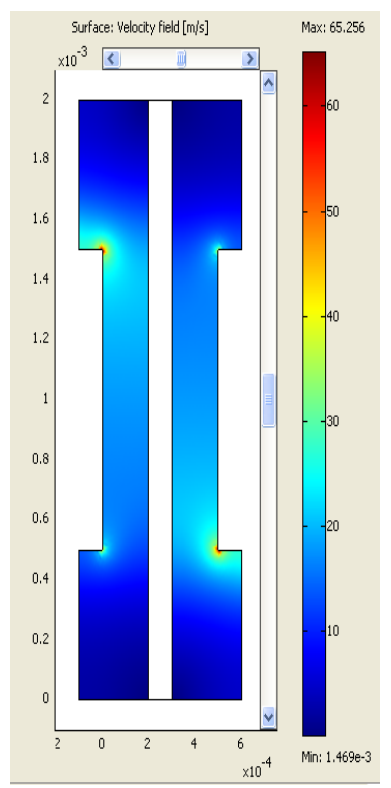

(b) Distribusi kecepatan

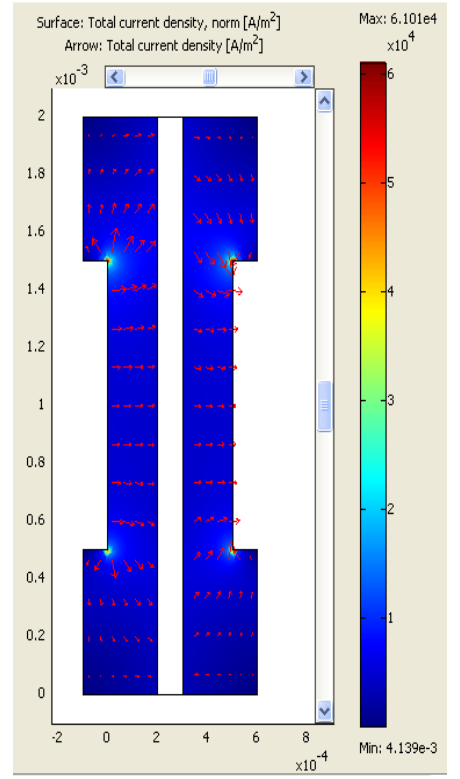

(c) Distribusi densitas arus

Gambar 8. Hasil Simulasi Tekanan Inlet Pa_in = Pc_in $=15$ psi.g

b. Simulasi temperatur operasi 343, 353 dan $363\left({ }^{\circ} \mathrm{K}\right)$ dalam gambar 9, 10 dan 11 berikut ini menghasilkan bahwa Nilai temperature operasi berbanding terbalik terhadap densitas arus. 


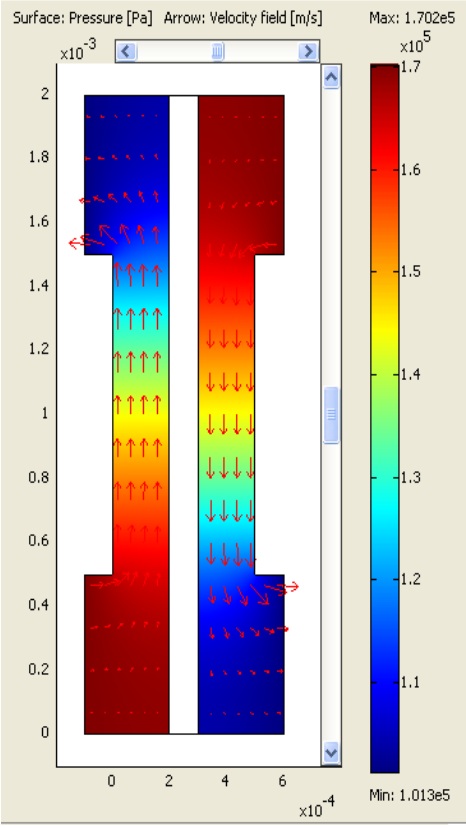

(a) Distribusi Tekanan

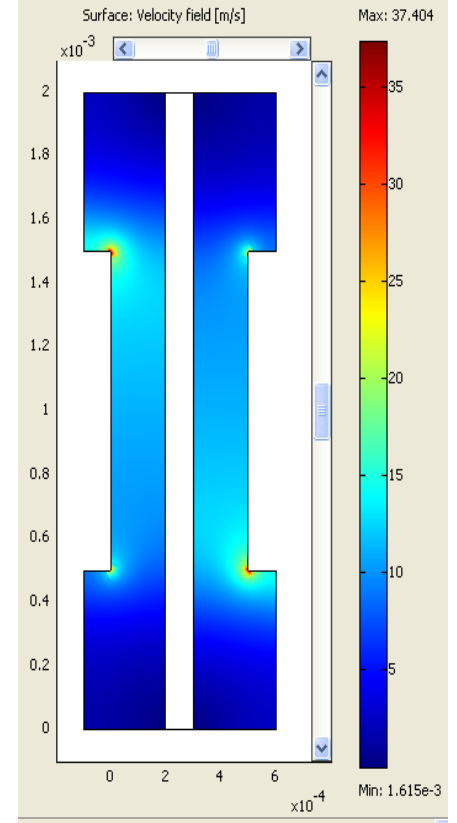

(b) Distribusi kecepatan

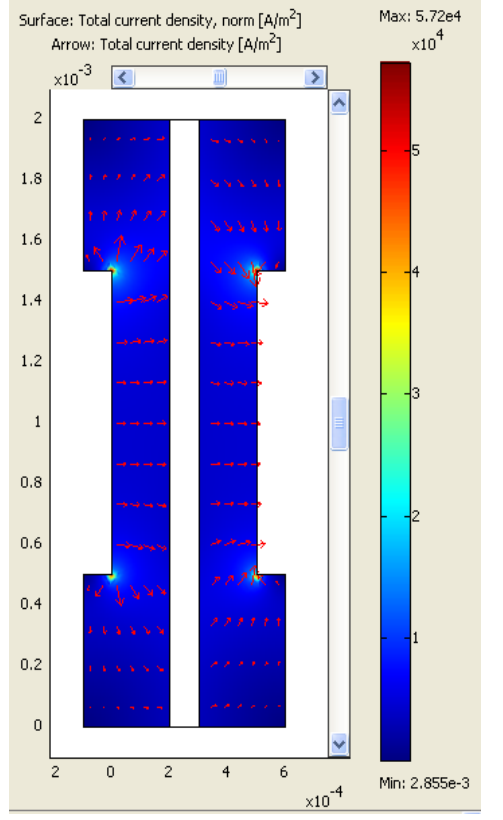

(c) Distribusi densitas arus

Gambar 9. Hasil Simulasi Temperatur Operasi T $=343{ }^{\circ} \mathrm{K}$

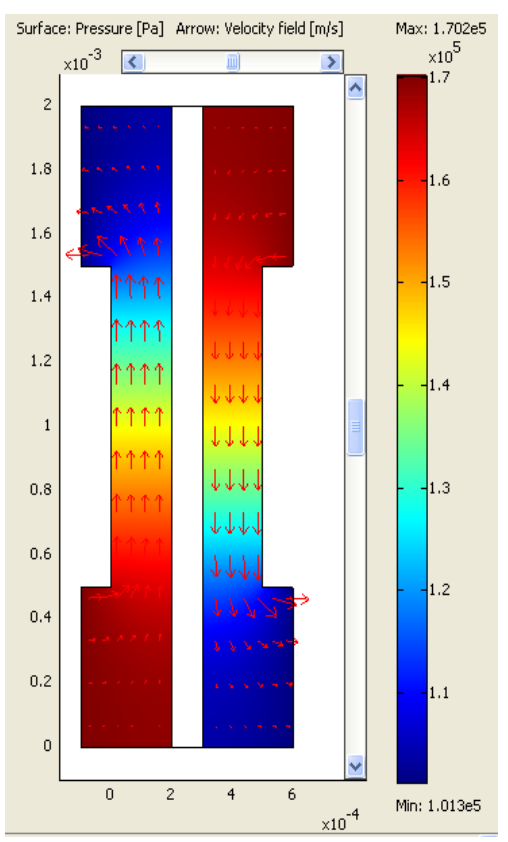

(a) Distribusi Tekanan

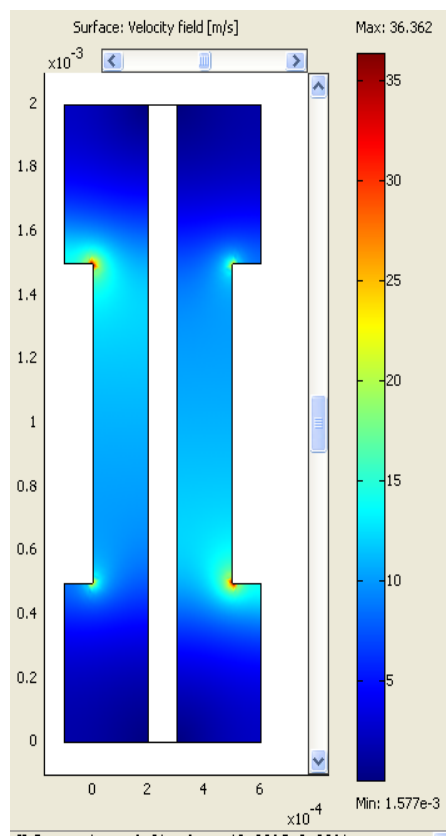

(b) Distribusi kecepatan

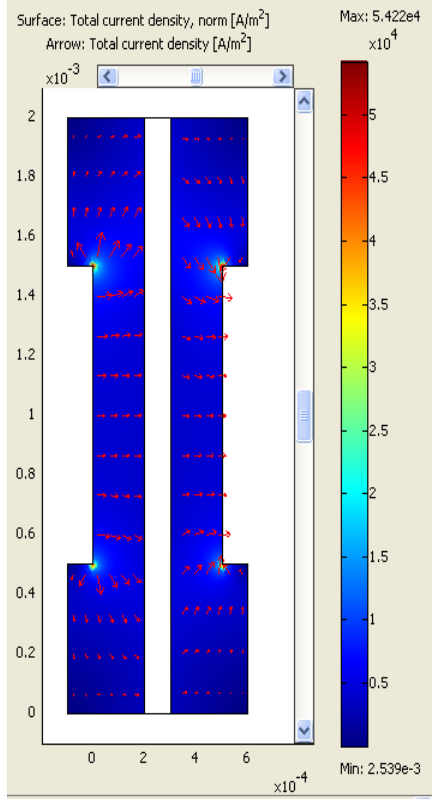

(c) Distribusi densitas arus

Gambar 10. Hasil Simulasi Temperatur Operasi $\mathrm{T}=353{ }^{\circ} \mathrm{K}$ 


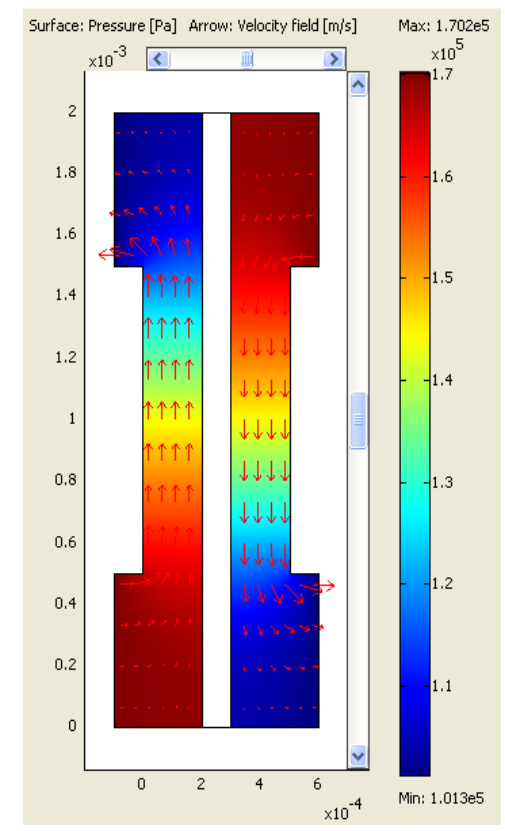

(a) Distribusi Tekanan

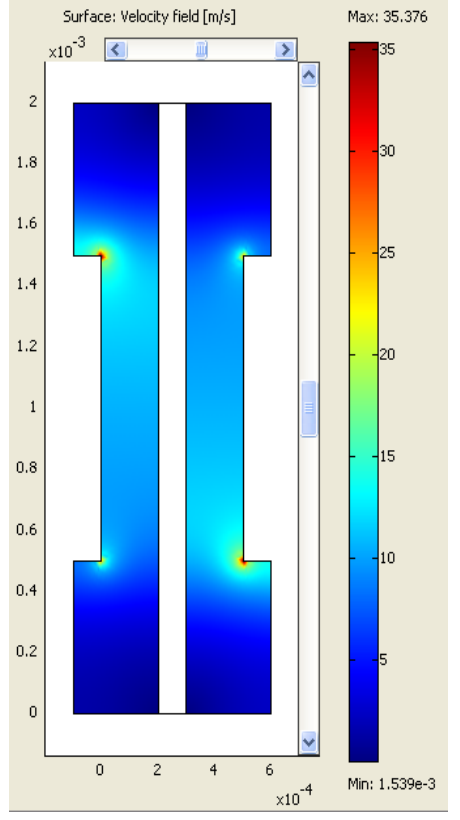

(b) Distribusi kecepatan

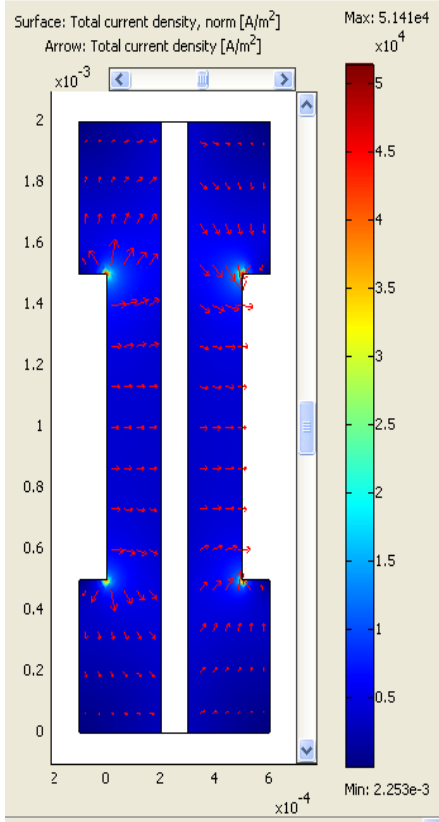

(c) Distribusi densitas arus

Gambar 11. Hasil Simulasi Temperatur Operasi $\mathrm{T}=363{ }^{\circ} \mathrm{K}$

c. Simulasi tegangan listrik operasi 0,$6 ; 0,7 ; 0,8(\mathrm{~V})$ yang ditunjukkan dalam gambar 12,13 dan 14 di bawah ini bahwa Nilai tegangan operasi berbanding terbalik terhadap densitas arus.

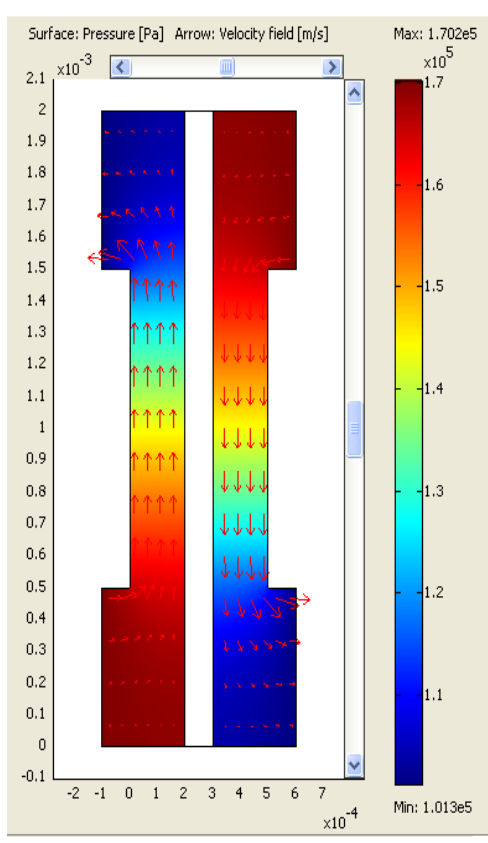

(b) Distribusi Tekanan

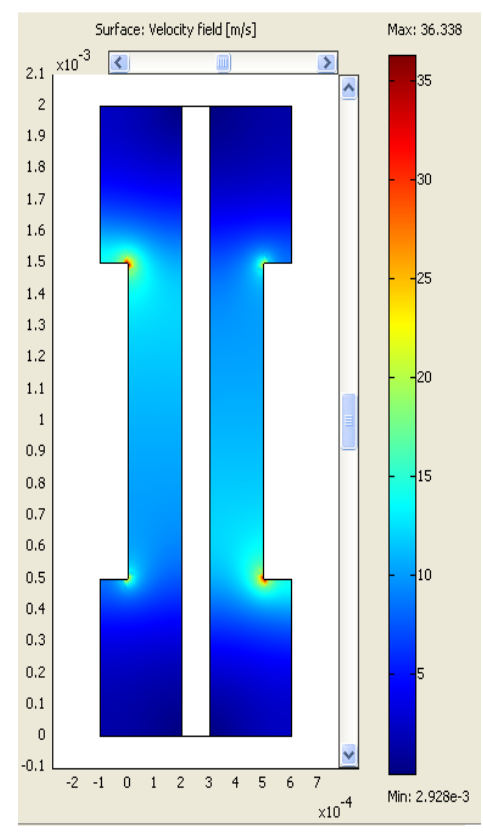

(b) Distribusi kecepatan

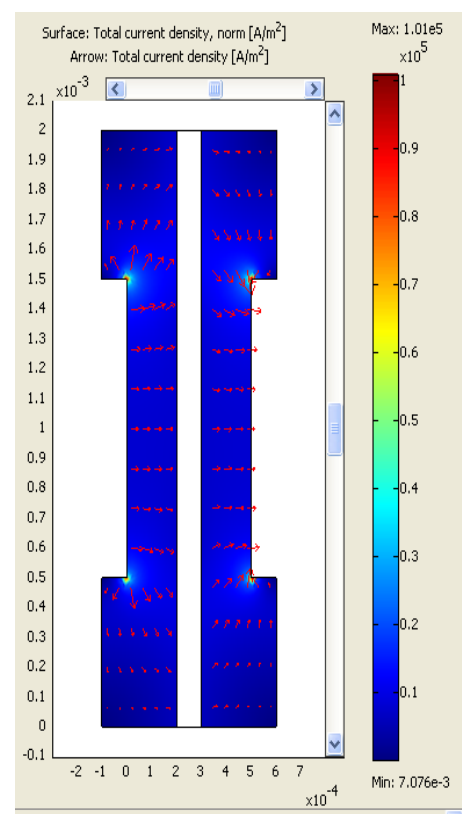

(c) Distribusi densitas arus

Gambar 12. Hasil Simulasi Tegangan listrik operasi Vcell = 0,6 V 


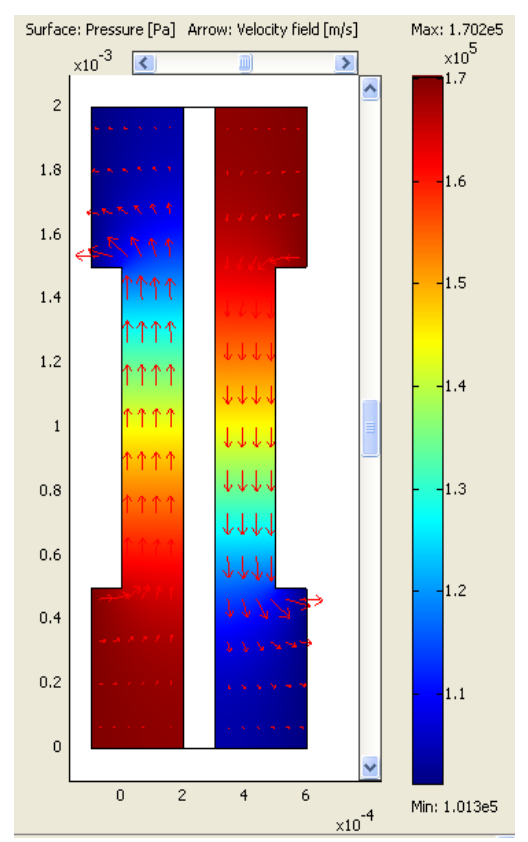

(a) Distribusi Tekanan

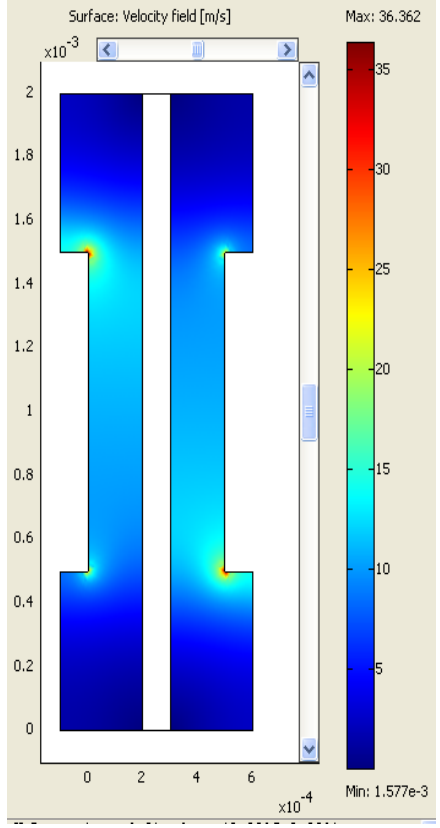

(b) Distribusi kecepatan

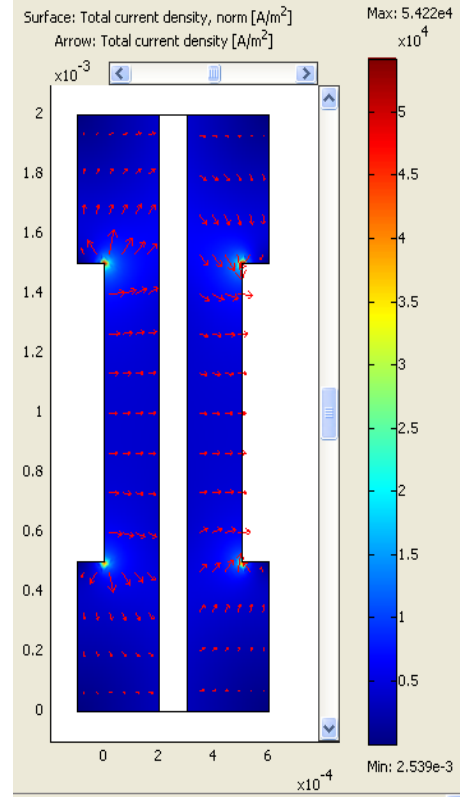

(c) Distribusi densitas arus

Gambar 13. Hasil Simulasi Tegangan listrik operasi Vcell = 0,7 V

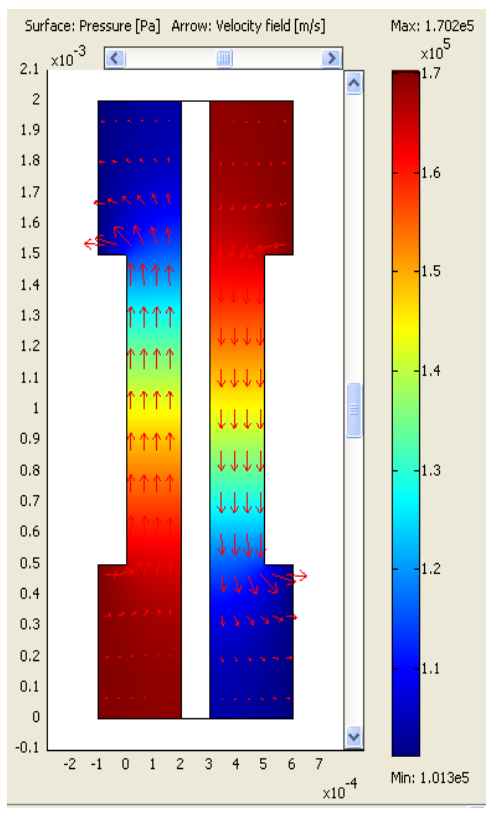

(a) Distribusi Tekanan

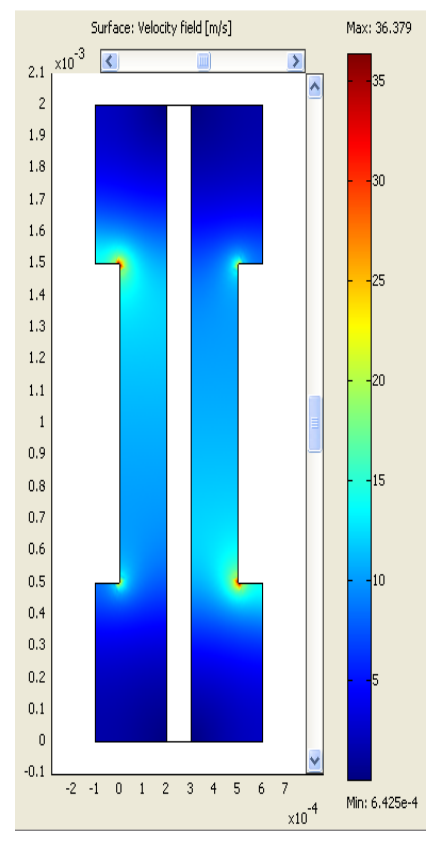

(b) Distribusi kecepatan

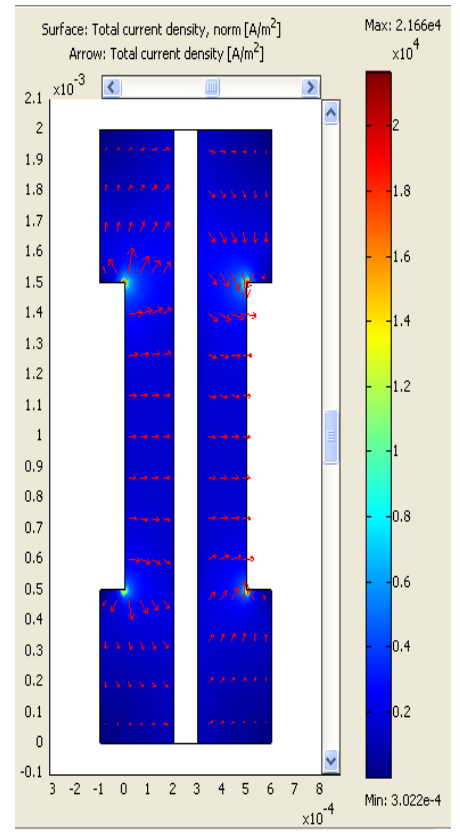

(c) Distribusi densitas arus

Gambar 14. Hasil Simulasi Tegangan listrik operasi Vcell $=0,8 \mathrm{~V}$

d. Simulasi porositas lapisan difusi 0,$2 ; 0,4 ; 0,6$ menunjukkan Nilai berbanding lurus terhadap densitas arus sebagaimana dalam gambar 15 berikut. 


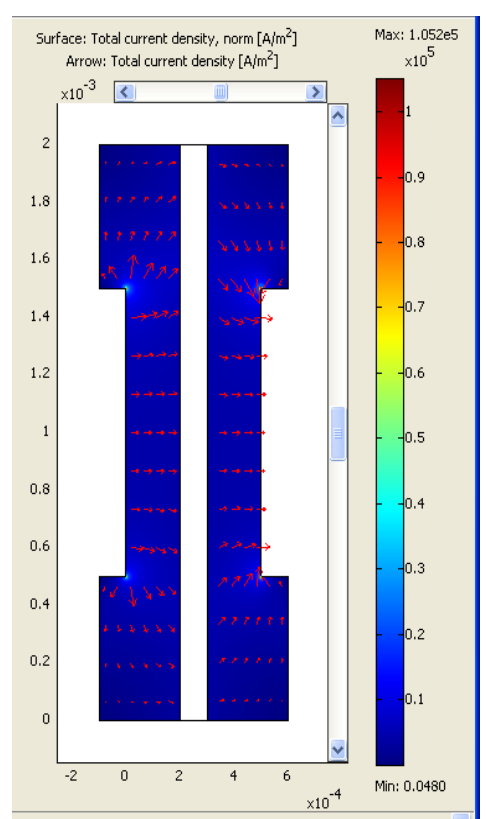

(a) emic $=0,2$

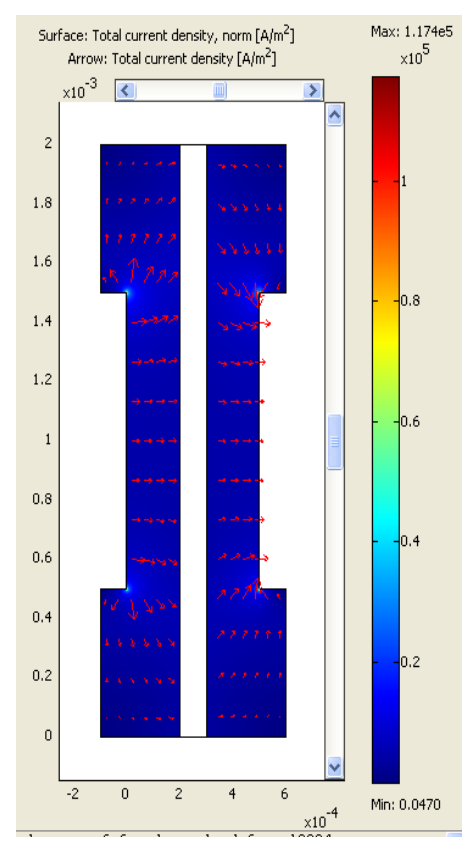

(b) emic $=0,4$

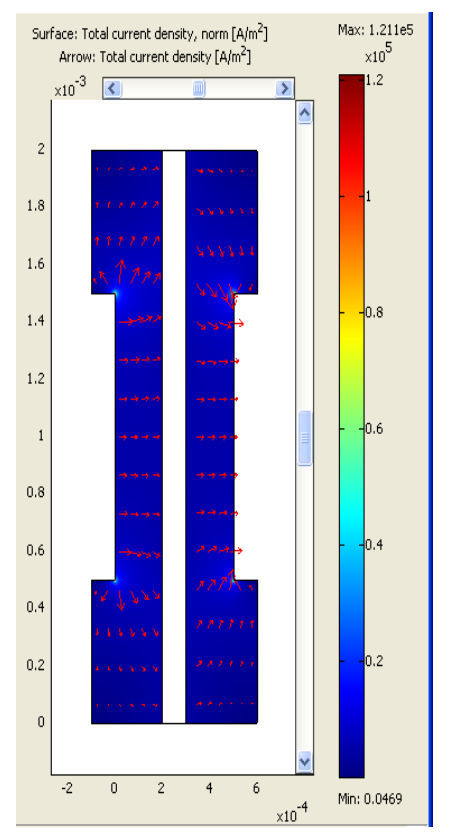

(c) emic $=0,6$

Gambar 15. Hasil Simulasi Porositas GDL untuk Porositas Katalis emac = 0,4

e. Simulasi kedalaman rib $1 ; 1,25 ; 1,5(\mathrm{~mm})$ pada gambar 16,17 dan 18 memberikan hasil bahwa Nilai kedalaman rib pada GDL berbanding parabolis dengan densitas arus

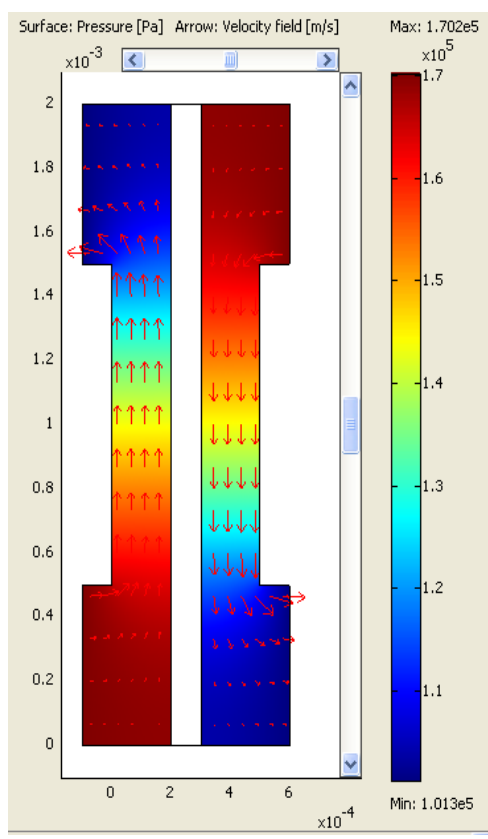

(a) Distribusi Tekanan

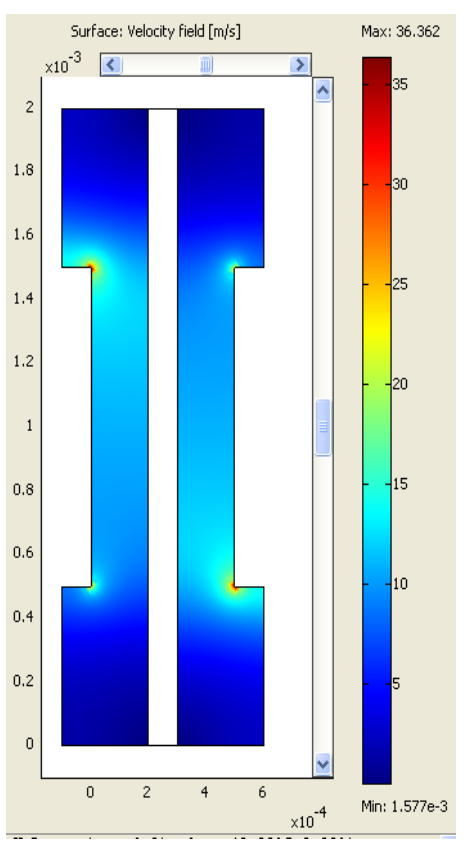

(b) Distribusi kecepatan

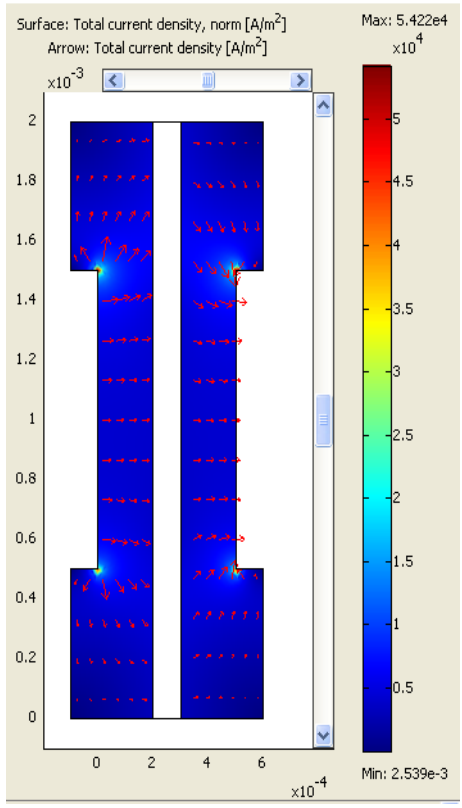

(c) Distribusi densitas arus

Gambar 16. Hasil Simulasi kedalaman rib 1 mm 


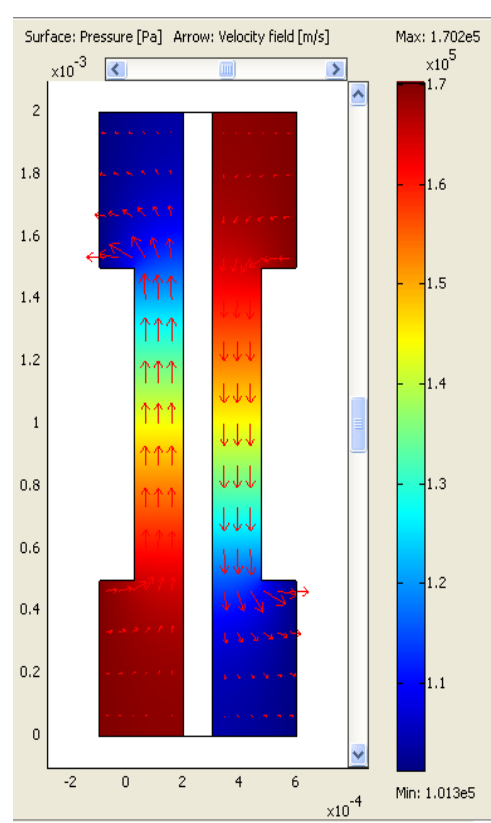

(a) Distribusi Tekanan

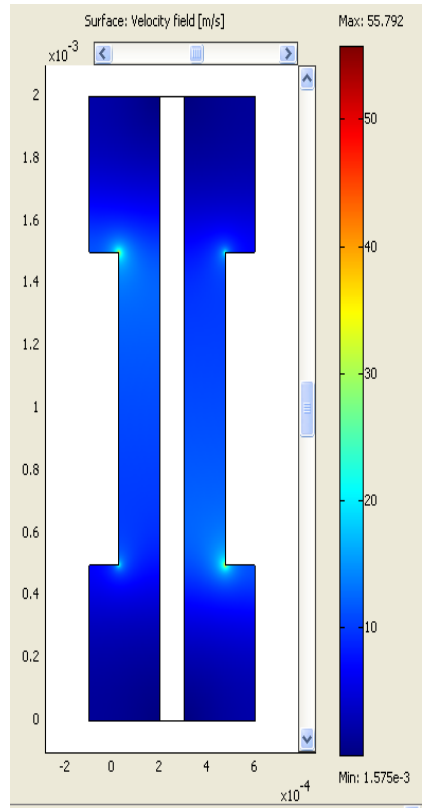

(b) Distribusi kecepatan

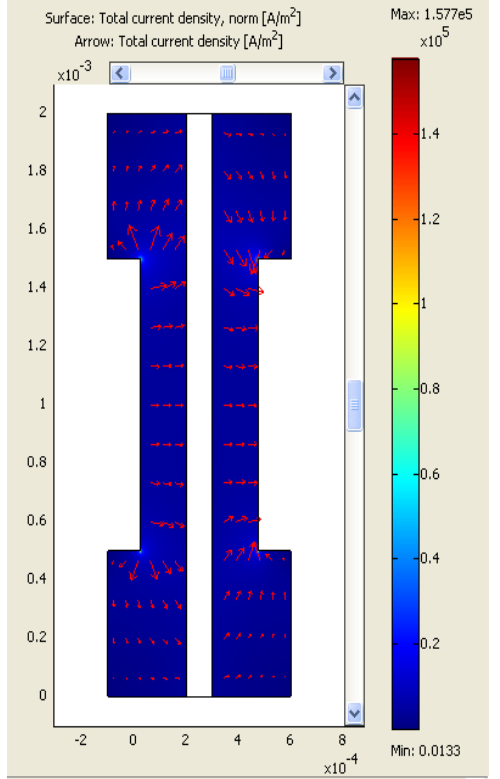

(c) Distribusi densitas arus

Gambar 17. Hasil Simulasi kedalaman rib 1,25 mm

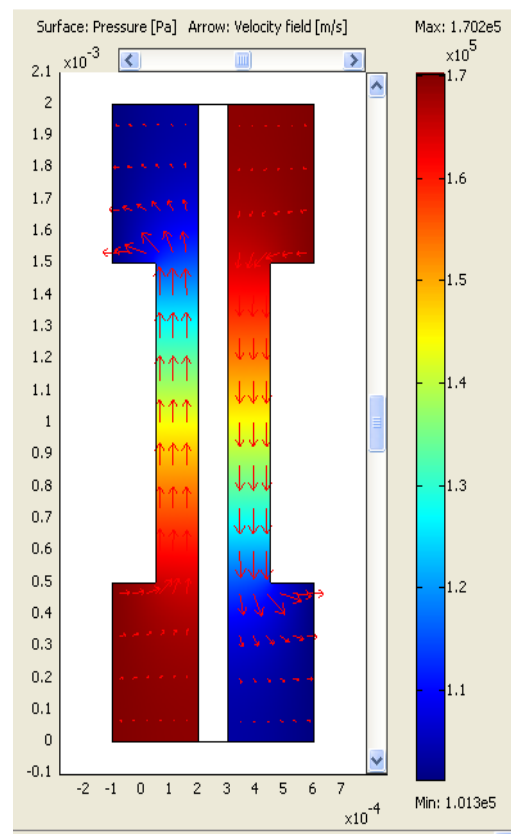

(b) Distribusi Tekanan

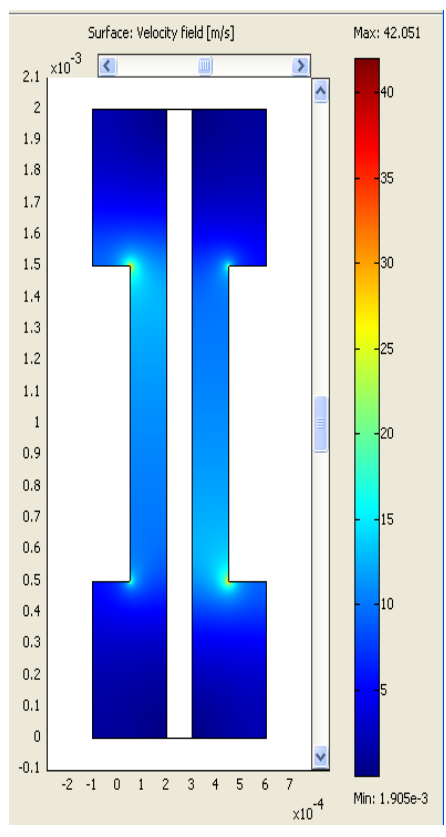

(b) Distribusi kecepatan

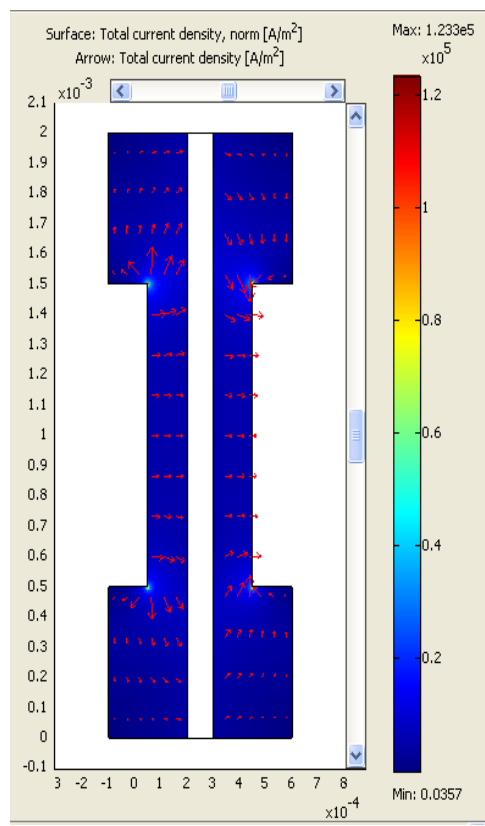

(c) Distribusi densitas arus

Gambar 18. Hasil Simulasi kedalaman rib 1,5 mm 


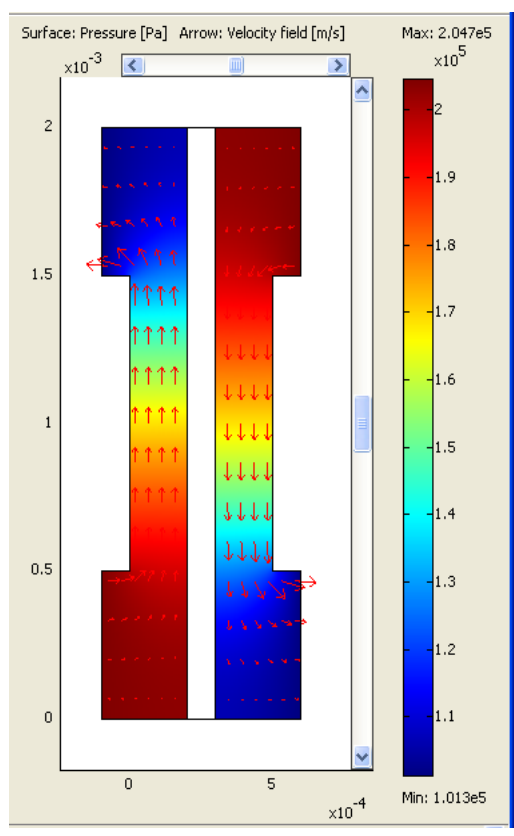

(a) Distribusi Tekanan

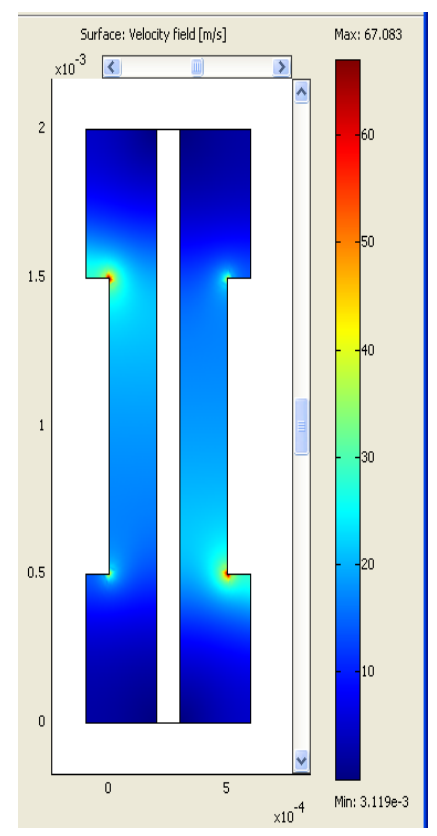

(b) Distribusi kecepatan

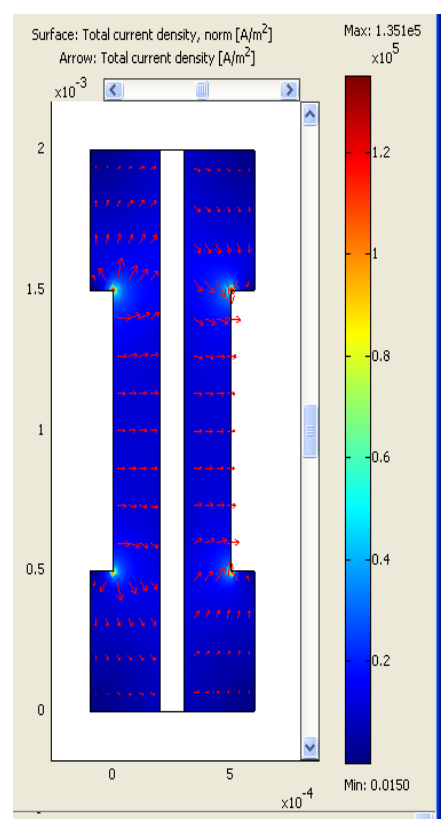

(c) Distribusi densitas arus

Gambar 19. Hasil Simulasi Optimasi Desain dan Operasi

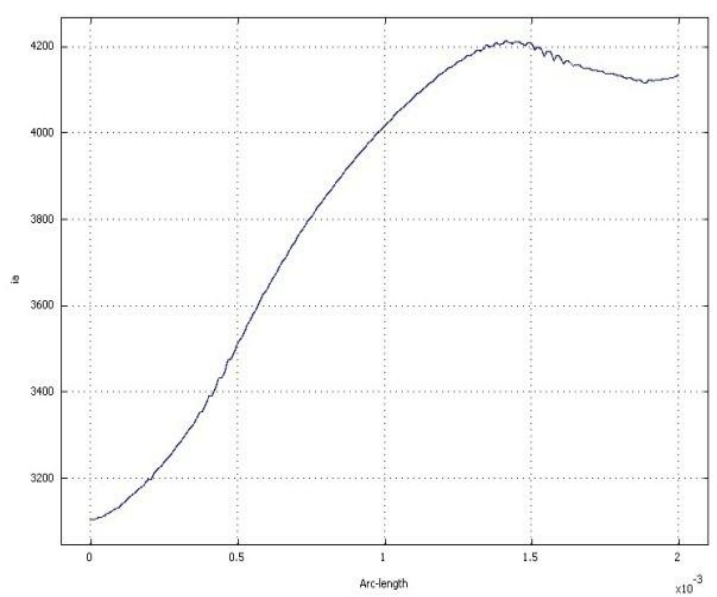

(a) Kondisi Initial

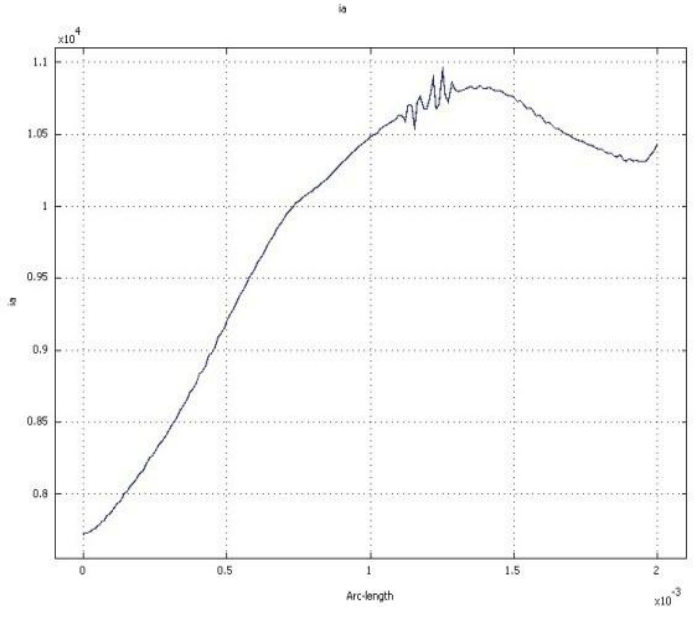

(b) Kondisi Optimum

Gambar 20. Hasil Simulasi Optimasi Desain dan Operasi Kinerja Densitas Arus katalis Anode 
Selanjutnya dari masing-masing efek parameter tersebut, maka dilakukan optimasi parameter desain dan operasi dengan criteria berikut, yang hasilnya diberikan dalam gambar 19 :
a. Tekanan optimum sebesar 15 psi.g
(Pa_in=Pc_in)
b. Temperatur operasi optimum sebesar $70{ }^{\circ} \mathrm{C}$
(T)
c. Tegangan operasi sel tunam sebesar 0,6 volt
(Vcell)
d. Nilai porositas katalis ditentukan sebesar 0,4
(emac)
e. $\quad$ Nilai porositas GDL ditentukan sebesar 0,6
(emic)
f. Nilai kedalaman rib pada GDL diambil sebesar $1 \mathrm{~mm} \mathrm{(depth)}$

Dari gambar 20 di atas grafik hasil optimasi parameter desain dan proses sel tunam diperoleh bahwa besarnya kinerja densitas arus anoda pada lapisan katalis menunjukkan nilai perbedaan antara kondisi inisial simulasi dan optimasi masing-masing sebesar $4200 \mathrm{~A} / \mathrm{m}^{2}$ dan $10750 \mathrm{~A} / \mathrm{m}^{2}$. Dapat dikatakan besarnya densitas arus katalis anode bertambah hingga $256 \%$ terhadap kondisi inisial.

\section{KESIMPULAN}

a. Kinerja sebuah sel tunam membrane pertukaran proton sangat ditentukan oleh parameter desain dan operasi yang digunakan.

b. Densitas arus memiliki korelasi proporsional secara linier terhadap parameter tekanan statis operasi, namun korelasinya menjadi berbanding terbalik oleh pengaruh besarnya temperature operasi, tegangan listrik operasi, porositas lapisan difusi gas dan kedalaman pelat electrode (rib) pada lapisan difusi.

c. Dari hasil simulasi pada parameter optimum operasi dan desain yaitu sebesar tekanan statis 15 psi.g, temperature saturasi air $70{ }^{\circ} \mathrm{C}$, tegangan listrik 0,6 volt, porositas lapisan difusi 0,6 dan kedalaman rib $1 \mathrm{~mm}$, diperoleh nilai optimasi densitas arus katalis anode sebesar $10750 \mathrm{~A} / \mathrm{m}^{2}$.

d. Terdapat kenaikan nilai densitas arus dari kondisi optimasi sebesar $256 \%$ terhadap nilai kondisi awal pada 10 psi.g, $80{ }^{\circ} \mathrm{C}, 0,7$ volt, porositas difusi 0,6 , porositas katalis 0,4 dan depth $1 \mathrm{~mm}$.

\section{UCAPAN TERIMA KASIH}

Penulis menyampaikan terima kasih atas kesempatan berkontribusi dalam Program Kegiatan Pengembangan Sel Tunam Membrane Pertukaran Proton (PEM Fuel Cell) yang dilaksanakan di Puslitbang Teknologi Energi Terbarukan dan Ketenagalistrikan Kementerian ESDM tahun Anggaran 2011.

\section{DAFTAR PUSTAKA}

[1] Koruplolu, V.B.R, et.al, 2015. "Effect of Parameters on The Performance of PEM Fuel Cell with Various Flow Field Geometries-A Theoritical Study." International Journal of Engineering Science \& Advanced Technology 5(2). 102-110.

[2] Kerkouf, Y., Ziari, Y.K., Benzaoui, A., 2013.'Effect of Pressure in Proton Exchange membrane Fuel Cell (PEMFC).” International Journal of Enegry Engineering 3(3). 158-164.

[3] Kahveci, E.E. and Taymaz, I. 2014. "An Investigation of GDL Porosity on PEM Fuel Cell Performance." Chemical Engineering Transactions 42. 37-42.

[4] Shokuhfar, A., Nejadseyfi, O., Zolriasatein, 2013."A Numerical Study of the Influence of Gas Diffusion Layer Porosity on Cell Performance of Counter Flow Proton Exchange membrane Fuel Cells." Iranica Journal of Energy \& Environment 4(2). 126-129.

[5] Wei, Y. and Zhu, H. 2011. "Model and Simulation of Proton Exchange membrane Fuel Cell Performance at Different Porosity of Diffusion Layer." I.J. Modern Education Computer Science 2. $22-28$.

[6] Ameri, M. and Oroojie, P. 2011. "Two Dimensional PEM Fuel Cell Modeling at Different Operation Voltages.", Proceeding World Renewable Energy Congress Sweden.

[7] Kahveci, E.E. and Taymaz, I. 2015. "Effect of Humidification of the Reactant Gas in the Proton Exchange membrane Fuel Cell.” Journal of Clean Energy Technologies 3(5.) 356-359.

[8] Ionescu,V. 2013 "High Temperature PEM Fuel Cell Steady State Transport Modelling." VERSITA Ovidius University Annals of Chemistry 24(1), pp 55-60. 
[9] Ionescu, V. 2014 “ Finite Element Method Modelling of a High Temperature PEM Fuel Cell.” Rom. Journ.Phy. 59(3-4). 285-294.

[10] Shi, Z., Wang X.,Zhang, Z. 2006. " Comparison of Two-Dimensional PEM Fuel Cell Modelling using COMSOL Multiphysics." Proceeding COMSOL Users Conference Boston.

[11] Pourmahmoud, N., et. al. 2011 "Three Dimensional numerical Analysis of Proton Exchange membrane Fuel Cell”. Journal of Mechanical Science and Technology 25(10), 2665-2673. 